\title{
An Early Response to Wahhabism from Morocco: The Politics of Intercession
}

\author{
Paul L. Heck \\ Georgetown University, Washington DC, USA \\ plh2@georgetown.edu
}

In what follows, I examine a refutation of Wahhabism written during the reign of Sultan Sulaymān of Morocco (r. 1792-1822) by one of the leading scholars of the realm, Muhammad al-Tayyib Ibn Kīān of Fez (d. 1812). The treatise, which is fairly lengthy, has been mentioned only cursorily in scholarly literature, mainly in the context of a delegation Sulaymān sent in 1811 to Sa'ūd b. 'Abd al-'Azīz (r. 1803-1814) in Arabia. ${ }^{1}$ The treatise, however, was written before these diplomatic maneuverings. Given its polemical tone, it clearly does not pretend to address the defender of Wahhabism in Arabia but rather has a domestic audience in mind. While not possible here to analyze the treatise exhaustively in its particular context, I do hope, in addition to summarizing its key points, to draw attention to the purpose for which it was likely written, namely to affirm the role of the religious scholar as interpreter of legitimate power.

Wahhabism justifies itself by attacking the long-standing practice in Islam of seeking a means to God (tawassul) through holy persons: prophets, saints, etc. Those who look to holy persons as mediators might have a specific request in mind, or they might simply hope for acceptance by God

1 The treatise is mentioned without discussion of its specific contents by Hamadi Redissi, "The Refutation of Wahhabism in Arabic Sources, 1745-1932," in Madawi al-Rasheed (ed.), Kingdom without Borders: Saudi Political, Religious and Media Frontiers (New York: Columbia University Press 2008), pp. 157-181, especially pp. 170-171. The treatise is also mentioned, in reference to Morocco's relations with Saudi rulers, by Muhammad al-Mansūr, al-Maghrib qabl al-Istimār: al-Mujtamic wa-l-Dawla wa-l-Dīn 1792-1822 (Casablanca: al-Markaz al-Thaqāfi al-'Arabī 2006), especially pp. 228-241. This work is not merely a translation but also a partial revision of Mohamed El Mansour, Morocco in the Reign of Mulay Sulayman (Wisbech: MENAS Press 1988). 
through the intercession of those who enjoy his favor. For Wahhabism, this is unconscionable innovation (bid'a), turning Muslims into idolaters. The practice, however, had long been approved, and religious scholars were quick to counter the claims of Wahhabism, already within the lifetime of its progenitor, Muhammad b. 'Abd al-Wahhāb (d. 1792). ${ }^{2}$

Debates over the mediation of holy persons continue in Islam today, and it is worth discussing the question before proceeding to our case. A canonical hadith speaks of the friends (or allies) of God (awliy $\bar{a}$ ' allah) acting as agents on his behalf. That is, their high level of piety makes them, in the wording of the hadith, God's eyes, ears, hands, etc. In this sense, while not divine, they share in divine agency, acting in a special way to represent God's purposes in the world. To this end, they are honored with various kinds of miracles (karāmāt): the ability to know the thoughts of others and to heal physical as well as spiritual ailments; the ability to act in ways that violate the customary order of the world, such as being in two places at once; and, less dramatically, the ability to attract and guide people to God as final end of human existence. Thus, whether alive in this world or "alive" with God after death, these figures offer a means (wasila) to God.

This has traditionally not been seen as a compromise of monotheism, since such figures are not viewed as deities but simply as friends (or allies) of God. While "deviant" behavior associated with the cult of the saints was criticized, most famously by Ibn Taymiyya (d. 1328), devotional attachment to holy persons itself was generally not defined as idolatrous, even by Ibn Taymiyya, until Wahhabism made attacks against it the basis of its mission. Wahhabism defines the practice as shirk, awarding to creatures powers that are proper to God alone. Particularly condemnable is the recourse to holy persons once dead. It is not inconceivable that a living person might help one obtain a goal, but the dead have no power. Indeed, they need the living to perform pious works on their behalf so as to increase their merit, helping them to a better outcome on judgment day. In no way is it permissible to seek the help of the deceased (al-istigātha bi-l-mawtā).

2 For the rise of Wahhabism, see Michael Cook, "On the Origins of Wahhabism," Journal of the Royal Asiatic Society of Great Britain and Ireland, Third Series 2 (1992), 191-202. For early responses to Wahhabism, see Samer Traboulsi, "An Early Refutation of Muhammad Ibn 'Abd al-Wahhāb's Reformist Views," Die Welt des Islams 42.3 (2002), 373-415; and R.Y. Ebied and M.J.L. Young, "An Unpublished Refutation of the Doctrines of the Wahhabis," Revista degli studi orientali 1 (1976), 377-397. 
This claim continues to be pressed in our own day, for example, by the well-known hadith scholar, Muhammad Nāsir al-Dīn al-Albānī (d. 1999), in a treatise titled Mediation: Its Types and the Rulings on Its Legal Status. ${ }^{3}$ Originally given as two lectures in 1972 at the author's home in Damascus, the treatise speaks to a modern form of piety that emphasizes, first, revelation as singular source of sound faith and, second, individual accountability before God, rejecting the mediation of others as a way to win divine favor. Arguing from the Qur'an and Hadith, the author arrives at three legitimate forms of mediation. The first is invocation of one of God's names (i.e. attributes) in seeking, for example, forgiveness of one's sins. The second is invocation of one's past pious works or good deeds. Here, the story is given of three men trapped in a cave. They all seek salvation from God by invoking a past meritorious act. This serves to mediate their need with God, and the boulder blocking the front of the cave is miraculously lifted. The third form of legitimate mediation is the invocation of a righteous man, usually the most righteous of the community, on behalf of a need, usually rain at time of drought. Here, too, it is not a person who acts as means to God but rather his invocation.

In general, Nāsir al-Dīn al-Albānī favors the second form (i.e. one's own meritorious acts) as agent of mediation, downplaying the idea of mediation through fellow creatures. ${ }^{4}$ His position follows from his overall conception of faith, which is centered on the idea that no creature has any right (haqq) over the Creator. He focuses his ire on the practice of mediation through relics, i.e. items that have come into contact with a holy person during his lifetime or with his shrine after his death. These are all innovations that lead to error and, in turn, to hell. This type of argumentation, upsetting long-standing devotional practices in Islam, exacerbates tensions within the umma, and so he condemns a piety that makes no distinction between monotheism and the intercession of holy persons who enjoy a divinely endowed agency to help those who look to them even after death. However, those who condemn these practices, such as Nāsir al-Dīn al-Albānī, have a more subtle message in mind. The Muslim ruler who allows such

3 al-Tawassul: Anwā'uhu wa-Ahkāmuhu, ed. Muhammad 'Abd al-'Abbāsī (Riyadh: Maktabat al-Ma'ārif lil-Nashr wa-l-Tawzī‘ 2001).

4 The one exception is the prophet, which the author accepts simply for the reason that Ahmad Ibn Hanbal (d. 241/855) did not object to it. While dismissing the mediation of other righteous figures, he records his awareness that leading scholars of the past permitted it, such as al-Shawkānī (d. 1834). 
idolatrous practices in his realm jeopardizes the legitimacy of his power. In other words, scholarly discourse on the cult of the saints makes scholars interpreters of legitimate power in Islam. The treatise of Ibn Kīrān, although arguing a very different position on the cult of saints, ultimately serves a similar purpose: It is by defending the cult of saints that he positions himself as scholarly interpreter of legitimate power.

Ibn Kïrān, a leading scholar of his day as shaykh al-jamāa $a$ in Fez, wrote on a wide range of religious topics, including works under the rubric of Sufism. For example, he composed a commentary on the mystical treatise (al-Hikam) of Ibn 'Atā' Allah (d. 1309) and another on the devotional prayer of the great patron saint of the Maghrib, Abd al-Sallām b. Mashīsh (d. 1228), ${ }^{5}$ the teacher of Abū l-Hasan al-Shādhilī (d. 1258). Ibn Kīrān also wrote a treatise on Sufism that suggests the influence of al-Ghazāli (d. 1111). ${ }^{6}$ His overall aim is twofold: first, to root Sufism more fully in the revealed sources of Islam; and second, to renew the scholarly ranks of his day. Two other works, still in manuscript, lay down both the foundations and the parameters of devotional attachment to saints.

Given his scholarly production, it is not surprising that Ibn Kīrān was the first in the Arab West to pen a coherent defense of the cult of the saints against the attacks of Wahhabism. He was no doubt personally committed to sainthood, but in defending it, he was also conveying a subtle message about power. To be sure, he was on close terms with the sultan, but the sultan was engaged in a struggle with other sources of power in the realm, especially networks of Sufism (turuq) and families of prophetic descent (shurafa $\vec{a}^{\prime}$. In this historical context, the question of power was deeply interwoven with debates over the piety of the realm. Thus, the treatise, a scholarly defense of devotional attachments to holy persons, also functions in its particular milieu to imply that it is the religious scholar who is interpreter of legitimate power.

It was during this period that the court instituted new religious policies, introducing to Morocco hitherto unknown forms of Islam that today are classified under the rubric of Salafism. ${ }^{7}$ The father of Sulaymān, Muhammad

5 See Zakia Zouanat, Ibn Mashīsh, maître d'al-Shādhilī (n.p. 1998).

6 This work, 'Aqd Nafā'is al-La'āl fì Tahrīk al-Himam al-'Awāl ilā al-Sumū ilā Marātib al-Kamāl, has recently been edited by Mustafā al-Hakìm in al-Ru'ya al-Sūfuyya ind al-Shaykh al-Tayyib Ibn Körān (Beirut: Dār al-Kutub al-'Ilmiyya 2007). The editor discusses the life and scholarly production of Ibn Kīrān, pp. 49-72.

7 See 'Abd al-Jalīl Bādū, al-Salafiyya wa-l-Islāh (Tangier: Salīkī Ikhwān 2007). 
b. 'Abdallah (r. 1757-179o), retained Malikism as the madhhab of the realm but rejected the scholasticism of Ash'arism, commanding that the formulation of doctrine be limited to the literal wordings of the revealed texts. Sulaymān, while restoring Ash'arism, took issue with the excesses of devotional practices, including practices that Ibn Kīrān would defend, composing sermons in which he attacked the use of song and dance to induce spiritual ecstasy, vows and animal sacrifices made to saints in their graves as well as the lighting of candles at their shrines, the mingling of men and women during devotional gatherings, and the pledge of allegiance made to the heads of the turuq. It is true that neither he nor his father sought to eliminate the core ideas of Sufism, an impossible task in Morocco. However, while their religious policies fell short of Wahhabism, they did encourage a kind of Salafism that would have allowed them to sidestep or even discredit other sources of power in society. In this fashion, they sought to position themselves, along with their scholarly allies, as the religious interpreters of their own power, giving them greater leeway to reform society under their sultanic aegis.

Why did the sultans want to reform society? An idealized vision of the past would attribute such top-down reformism to external threats from European powers. This view attributes the advance of the infidels to a weakness of national spirit that itself is seen as byproduct of religious lassitude among the masses. ${ }^{8}$ This line of reasoning is not without merit, even if European encroachments were not at this time what they were to become. Still, the more likely motive was the need of the sultans to bolster their own sovereignty over other sources of power in society by becoming religious reformers in their own right.

Why should religious reform be part of the process of bolstering political sovereignty? The history of Morocco in general suggests that the contestation for prestige in society centers on the cultivation of piety (i.e. closeness to God), including the ability to protect the realm from religious innovation that threatens its standing with God. This period certainly saw its share of powerful reform movements with the potential to style themselves as authoritative interpreters of power, most notably the movement led by Muhammad al-'Arabī al-Darqāwī (d. 1823). The sultans of Morocco have always sought to manage the religious arena in part by allying with certain charismatic figures against others, and this was no less the case at a time

8 For such a view, see 'Abd al-Qādir al-'Āfiyya, al-Maghrib wa-l-Jihād al-Ta'rīkhī, 2nd ed. (Sale: al-Ma'had al-Mutakhassis lil-Tiknūlūjiyya al-Tatbīqiyya 1999). 
when groups such as the Raysūniyya, the Wazzāniyya, the Nāsiriyya (to which Ibn Kīrān belonged), and the Tijāniyya, enjoyed significant influence in society alongside the Darqāwiyya.

It is worth mentioning one example of this intra-Muslim rivalry that would have made for a more dynamic religious arena but also one more challenging to manage: Muhammad b. 'Abd al-Salām al-Nāsirī(d.1239/1823), who apparently enjoyed Sulaymān's favor, wrote a treatise criticizing the innovations - he lists sixty - that his paternal cousin had introduced into the practices of the Nāsiriyya (founded in 1575), rendering the zāwiy $a$ a site of bogus rituals rather than a place of spiritual renewal. ${ }^{9}$ Clearly, there was a "political" motive behind the treatise. Its author undoubtedly wrote it to demonstrate that he was more fit than his cousin to lead the Nāsiriyya. Still, to judge from some of the innovations mentioned, such as the practice of postponing prayer in the absence of the leader of the zāwiya, there may well have been need for a certain reform. Al-Nāsirī did not attack the cult of the saints itself. Rather, his attack on innovation is meant to establish his authority over the institution. Similarly, the sultans, initiating a policy of religious reform against innovation, were casting themselves as authoritative interpreters of the religion of the realm - and thus of their own power.

Ibn Kīrān's treatise thus reflects a particular moment in Morocco's history, when the call for reform offered a way for various actors, including sultans, both to advance their interests and to restore the religious integrity of the realm. At all times, the concept of innovation in religion, implying a kind of corruption in society, is deployed to signal the need for reform while at the same time acting as a rhetorical strategy to assert oneself over one's religious competitors. ${ }^{10}$ There were political interests at play in this context as in others, but it is important to appreciate the real anxiety over

9 Muhammad b. 'Abd al-Salām b. 'Abdallah al-Nāsiri, al-Mazāyā fìmā Uhditha min al-Bida' bi-Umm al-Zawāyā, ed. 'Abd al-Majīd al-Khayāllī (Beirut: Dar al-Kitāb al-'Ilmiyya 2002).

10 It was certainly used for this dual purpose during the reigns of the two sultans under consideration here. They both advanced a kind of Salafism to reform the beliefs of the realm and garner religious authority for themselves. Indeed, Sulaymān, reversing the policies of his father, went so far as to ban extra-shari'a taxes (mukūs) and forbid tobacco cultivation, presumably to the detriment of his treasury. He also promoted the teachings of Abū Hāmid al-Ghazālì (d. 1111), as a model of true Sufism by which to treat the religious shortcomings of the realm in relation to Sufism, and he co-authored with Ibn Kīān a treatise on kasb, arguing that humans have a power over their own actions even if they are under the command and will of God. It is difficult to surmise from all this that his reformism was 
innovation, specifically the implication that Muslims were no longer living by the guidance that God had originally revealed to Muhammad. In short, there was more at work in the reformism of the sultans than a simple desire to consolidate power.

To this end, Muhammad b. 'Abdallah not only tried to do away with Ash'arism but also discouraged the study of figh in favor of direct scholarly engagement with the texts of revelation. Such a move met the objections of scholars whose prestige is based on mastery of $f i q h$, but there is more to the story than concern for lost prestige. The sultan may have thought that by demoting figh he could more easily issue decrees without the approval of the religious scholars, but he hardly cut ties with scholarly circles. Rather, it is worth considering the piety of the sultan. ${ }^{11}$ Operative within his religious vision was a fine theological issue that was by no means historically determinative but that would have had resonance in the debates and struggles of the day. Muhammad b. 'Abdallah did have a genuine concern to cultivate greater piety in the realm, and for that purpose he rejected the principle of taqlid. He took this position on the basis of his own brand of piety that would question the religious integrity of Muslims who base their faith on the teachings of authoritative scholars rather than their own understanding of revelation.

The principle of taqlïd does serve the prestige of religious scholars, since it makes their scholarly authority the basis of the community's faith. In that sense, the sultan's rejection of it was not without political import. Still, more is at stake. The dismissal of taqlid, while viewed favorably by the "modern" mindset, has the potential to unsettle a society that evaluates itself in terms of its religious integrity. It is one thing for such a society to find assurance of its religious integrity in the presence of scholarly virtuosi, however few in number, whose knowledge serves to guide the realm. It is another thing to suggest that the faithful at large are themselves responsible for the religious integrity of the realm, and this is what the reform of Muhammad b. 'Abdallah implied.

Thus, motivated by pious concerns no less than the sultan, scholarly circles looked askance at such a development not simply as a threat to their

less than genuine even if coalescing with his politics. See, for example, 'Abd al-Jalīl Bādū, al-Salafiyya wa-l-Islāh (Tangier: Salīkī Ikhwān 2007).

11 See Ahmad al-Amīn al-'Amrānī, al-Haraka al-Fiqhiyya fì 'Ahd al-Sultān Muhammad Ibn 'Abdallāh al-'Alawī, 1171-1204/1757-179o, 2 vols. (Rabat: Wizārat al-Awqāf wa-l-Shu'ūn al-Islāmiyya 1996). 
standing but also for its unsettling effect on society as a whole. To sure, believers are to be held to standards, however minimal, but expecting too much from them opens the door to accusations of infidelity, such as the accusations of Wahhabism, when they fail to meet such expectations. The rejection of taqlid had the potential to cast suspicions on the religious integrity not only of the masses but also of the bulk of the scholarly class. Who, after all, could be counted as a mujtahid with the right of engaging the texts of revelation directly? The ranks of students, it was felt, were by no means qualified to acquire knowledge through a direct engagement of the texts of revelation. There had to be an intermediary step via abridgements, such as the abridgement of Khalil (d. 1374), a key architect of Malikism. The court's policy therefore risked creating chaos in society by tying soundness of faith to individual effort (ijtihad) to understand the texts of revelation apart from the mediation of scholarly abridgements, commentaries, etc.

At stake, then, amidst the struggles for power was the religious integrity of the realm. This was not a new concern. The idea that the soundness of faith is based on the teachings of others raises questions in every age about the religious status of those whose faith is a function of taqlid rather than ijtihād. The possibility that the faithful at large (al-'awāmm) were actually infidels had long been a concern in the Maghrib, but earlier efforts to counter it took a tactic different from that of the sultan's rejection of taqlid. For example, 'Abd al-Wāhid Ibn 'Āshir (d. 1630) wrote al-Murshid al-Mu in 'alā l-Darürì min Ulüm al-Dìn, a short treatise in rhymed prose that made the essential elements of the faith more accessible to the masses-Ibn Kinān wrote a commentary on it-with the purpose of preserving them from unwittingly lapsing into infidelity. Such a situation had practical consequences: Some scholars might refuse to recognize a man as a Muslim, barring him from marrying a Muslim woman, if unable to demonstrate a basic understanding of the core tenets of the faith without reference to the authority of others.

The arguments of Wahhabism, which may have trickled into Morocco during the reign of Muhammad b. 'Abdallah, ${ }^{12}$ would have sharpened these

12 Ahmad al-Amīn al-'Amrānī in the work cited above claims that Sultan Muhammad knew of Wahhabism, which is what motivated him to institute his new religious policies. It may not be unreasonable to suppose that individual Moroccan scholars, in search of knowledge in the East, relayed knowledge of the tenets of Wahhabism to Morocco, even if the challenge of Wahhabism did not appear in full force, politically and religiously, until the reign of Sultan Sulaymān. One example of a scholar from the Maghrib who developed a more rigorous piety as a result 
long-standing sensitivities. Wahhabism as a movement became an official concern only in 1803 with the attacks on Moroccan pilgrims in Arabia. However, as a "concept," it would have functioned as a tool in domestic competition for religious preeminence. This certainly was the case in subsequent periods up until today. ${ }^{13}$ For example, Abu l-Qāsim al-Zayyānī (d. 1833), who was opposed to the Tijāniyya, equated it with Wahhabism. Thus, by defining Wahhabism as beyond the pale of Islam, he was, by association, casting the Tijāniyya as unorthodox. In contrast, Muhammad Akansūs (d. 1877), a leading member of the Tījāniyya, saw Wahhabism as fanatical but did not consider it to be beyond the pale. Thus, when speaking positively of Wahhabism, he is also defending the Tijāniyya from the likes of al-Zayyānī.

There is no denying the new forms of piety in the religious policies of the court, but it could also be said that Sulaymān — and his father before him made use of Wahhabism in the sense just suggested: not with the purpose of adopting it in all its particulars but as part of the process of asserting authority over rivals in the religious arena. He did patronize Ahmad al-Tijānī (d.1815), so there is no question of his having adopted Wahhabism, ${ }^{14}$ but he may have deployed it as a concept in his policy of restricting the saintly festivals. In denying the masses access to the shrines, a point of agreement with Wahhabism, he was not rejecting sainthood but rather claiming authority over the piety of the masses who, in his view, did not have exact knowledge of the fine points of sainthood, causing them to fall into polytheism during the festivals of the saints.

of travels in the East, albeit from a period prior to Wahhabism, is Muhammad b. Sulaymān al-Maghribī (d. 1683). See Basheer M. Nafi, "Tasawwaf and Reform in Pre-Modern Islamic Culture: In Seach of Ibrāhīm al-Kūrānī," Die Welt des Islams 42 (2002), 307-355.

13 Advocates of Salafism in contemporary Morocco, which is a Salafism more closely aligned with Wahhabism, conflate the Salafism of the two sultans discussed here with the contemporary brand. The idea is that rule under the guidance of this kind of Salafism has a long history in Morocco and would be the normal state of affairs had it not been for the machinations of the French protectorate and its postcolonial successors. See, for example, the series of articles by Hammād al-Qibāj in al-Sabil, a bi-monthly journal in Morocco. I have had access to two articles in the series (titled "al-Salafiyya wa-l-Dawla: Ayy 'Ilaqa?"): al-Sabïl, no. 54, May 16, 2009, p. 14 and no. 55, June 1, 2009, p. 14.

14 It should be noted that Moroccans participated in the war against Wahhabism under the command of Muhammad 'Ali Pasha of Egypt, who in 1815 defeated 'Abd Allah b. Sa'ūd (later executed in Istanbul in 1818). 
In other words, Wahhabism became simply another reference point in an already existing debate over definitions of Islam in the Maghrib in the late eighteenth and early nineteenth centuries. In this sense, it would have been necessary for a scholar of the stature of Ibn Kīrān to represent his authority on an issue, namely the cult of the saints, which was already the most controversial topic of the day and which the arguments of Wahhabism had made even more so. By composing a treaty that brought scholarly acumen to the topic, he was informing his society, including the sultan, where the basis of legitimate power lay, namely in defending the formulation of religion set down by the religious scholar. In this sense, then, the treatise serves to underscore the role of the religious scholar as interpreter of power in Islam.

Wahhabism became an official concern in the Maghrib in 1803 when Moroccan pilgrims were attacked. Some were even killed. They had also been prevented from visiting shrines and reading Dalä'il al-Khayrāt, a book of devotional prayers composed by al-Jazūlī (d. 1465), one of the great figures in the history of Sufism in Morocco. This put a stop to pilgrimage caravans from Morocco, which had been suspended during the French invasion of Egypt, 1798-1802. Also in 1803, the sultan's emissary, Ahmad b. 'Abd al-Salām al-Bannānī, brought back two letters on the teachings of Wahhabism from Sa'ūd b. 'Abd al-'Azīz (r. 1803-1814). In 1811, a third letter arrived, forwarded from the religious scholars of Tunis. This offered Sulaymān the opportunity to establish contact with the Saudi ruler in order to secure the safety of the pilgrimage, thereby bolstering his prestige within the religious arena.

He sent his son Ibrāhīm as head of a delegation to Sa'ūd b. 'Abd al-'Azīz to inquire into the nature of Wahhabism. With Ibrāhīm, Sulaymān sent a qasìda, composed by Hamdūn b. al-Hājj (d. 1817), a leading scholar of Fez and pupil of Ibn Kīrān, and a letter, penned by Ibn Kīrān in the name of the sultan, which was diplomatic in nature, praising Sa'ūd for combating innovation and ensuring the security of the Hijaz, but also cautiously expressing reservations about the nature of Wahhabism, not only its practice of condemning Muslims who oppose its doctrine but also its position on holy persons: Does Wahhabism hold that the prophets are dead in their graves? And what is its position on shrine visitation? The letter was careful to distinguish between those who sought the intercession of holy figures, knowing full well that all power lies with God, and those who do so thinking that these figures in their graves had the power to influence the outcome of their petitions. In the exchange, as recorded by Muhammad Akansūs, Sa ūd 
responded that the prophets are indeed alive in their graves but that he prevents the faithful from visiting their graves lest they associate them with divinity or seek from them petitions that only God in his singular lordship can grant. This made sense, of course, to Sulaymān. While operating in a very different context, he too had sought to restrict such visitations as a way to show his responsibility for the religious integrity of the masses.

A diplomatic exchange is one thing. A scholarly treatment of the religious agency of holy persons is another. In light of the foregoing, it is more accurate to conclude that Ibn Kīrān's refutation of Wahhabism, although also written at the request of Sulaymān, was not part of a diplomatic strategy. After all, it refers to the author of the aforementioned letters as "the agent of innovation" (al-mubtadi ${ }^{c}$ ), language hardly appropriate for a diplomatic mission, and it was written before the delegation to Arabia, although it is difficult to specify the exact date. The earliest date is 1803 , since it refers to the letters of Sa'ūd that al-Bannānì delivered to the sultan. In any event, the treatise defends a traditional understanding of holy persons in a way that the reformist atmosphere of the day would have required. In this sense, in light of the foregoing discussion, it is possible to view the treatise as the work of a religious scholar who aims not simply to refute a new form of Islam but, more specifically, to assert the authority of the scholarly class by defining the religion that is to prevail in the realm, especially in relation to the most controversial issue in the religious sphere. We now turn to a summary of the treatise.

The treatise begins by referring to a group from the East that has troubled the doctrines of Muslims at large ('ämmat al-musliminn), condemning as infidels (takfir) all those in the umma who oppose their creed. ${ }^{15}$ This group uses evidence (daläil, i.e. from the texts of revelation) to advance false arguments that charm the faithful, and Sultan Sulaymān has commanded Ibn Kïrān to examine their arguments, especially the points that appeal to people at large, and to refute them where necessary. The point, then, is neither to address the purveyors of Wahhabism in Arabia nor to

15 The treatise was published on the margin of another work. See Abū 'Abd Allah Muhammad b. Mustafā al-Hasan̄i, Kitāb Izhār al-Huqūq fì l-Radd 'alā man Mana'a al-Tawassul ilā Allah Ta'ālā bi-l-Nabì wa-l-Walī. Wa-bi-hāmishihi mu'allaf jalìl fíl-Radd 'alā l-Mubtadi'a min al-Tā'ifa al-Wahhābiyya li-'Abd Allah Muhammad b. 'Abd al-Majìd b. 'Abd al-Salām b. Kìrān al-Fāsī (Cairo: Mațba'at al-Taqaddum al-'Ilmiyya 1909). 
reject their creed wholesale but rather to manage its effects on the religious arena at home.

Ibn Kïrān first turns to the question of faith. He has to walk a fine line. On the one hand, he has to offer a definition that is broad enough to protect the umma from the condemnations of Wahhabism. On the other, his definition has to speak to the more general concern that Muslims at large do not actually understand the faith. He therefore defines faith quite simply, in the fashion of al-Ghazālī, as trust (tasdīq) in the message of the Prophet Muhammad, but he ties it, in principle, to three conditions: comprehension of the message with no contradiction; conviction in the heart; and submission to the message in life. (Interestingly, Ibn Kīrān cites here "the people of the book" from his own society who, in his view, comprehend the message of Islam and recognize its truth, fulfilling the first and second conditions, but remain infidels for refusing to follow it.)

What, then, would indicate that one is a Muslim? It would require, first of all, the presence of external evidence that one trusts the message of the prophet, namely pronunciation of the two testimonies of faith (i.e. that there is no god but Allah and that Muhammad is Allah's messenger). It would also require the absence of external evidence that one does not trust (takdhīb) the message of the prophet. Such evidence includes wearing the attire of Jews and Christians, prostrating to the sun and idols, showing disdain for the prophets and the Ka'ba, and throwing the text of the Qur'an in the dirt. Thus, the pronunciation of the two testimonies sufficiently qualifies a person as a Muslim in good standing. Of course, Ibn Kīrān cannot ignore the fact that many Muslims do not perform their religious duties. He gets around this by speaking of gradations of faith. One who does not perform all that Islam requires is not denied the status of Muslim but rather has failed to reach the perfection of Islam (kamäl al-isläm). The details of the faith, while integral to Islam, cannot be equated to faith itself but function, rather, in the way one names something by the things that bring it about (tasmiyat al-shay' bi-smi sababihi).

The discussion of faith sets the stage for Ibn Kïrān to address the specific accusations of Wahhabism. This comprises the bulk of the treatise. The goal is to demonstrate that devotional attachment to prophets and saints, including the practice of seeking their intercession to obtain a request, is not tantamount to idolatry (shirk). In this sense, a scholarly discussion of such questions, using Wahhabism as foil, would have served not only the sultan in his attempts to establish his authority over the masters of institutional Sufism but also that of the scholarly class as arbiters of sound piety. 
Ibn Kīrān performs masterfully. Drawing on the texts of revelation and scholarly consensus, he shows that the various practices associated with the cults of the saints, excesses not withstanding, do not amount to idolatry since they in no way involve the attribution of lordship or divinity to those persons who are the objects of devotional attachment.

He begins his defense by exposing the faulty analogy (qiyās fāsid) at the heart of the claim that devotional attachment is a kind of idolatry. The flaw lies in the conflation of such devotion (ta'alluq) to the worship of idols ( ibädat al-asnām) against which the Qur'an warns, as if both are a kind of worship of something other than God ( ibäda li-ghayr allah). The attacks of Wahhabism against the umma are, then, entirely baseless, since they all stem from this faulty analogy. The specific problem lies in the assumption that the verses in the Qur'an that warn against idolatry issue a cause ('illa) with universal applicability. Those verses that command worship of God have universal applicability, but those that warn against idolatry, in contrast, apply only to the specific situation where people attribute lordship (rubübiyya) or divinity (ulühiyya) to the creatures whose assistance is sought. This, Ibn Kīān admits, is not to deny that some aspects of devotional attachment take on something of the quality of idolatry, but this condition, short of attributing lordship and divinity to the holy persons, is not grounds for takfir.

At this point, Ibn Kīrān turns to the definition of worship. Prostration alone is not enough to qualify as worship, since that would impute idolatry to the angels who prostrated to Adam and also to Joseph's brothers and parents who bowed down to him. Notwithstanding Islam's prohibition of prostration (sujüd) to creatures, worship is not simply the action of abasing and subjugating oneself to another (al-tadhallulwa-l-khud $\bar{u}$ ). In any event, devotional practice in Islam does not include such action. The upshot, Ibn Kirān concludes, is that the practice of seeking the assistance and intercession of saints is a kind of invocation $\left(d u^{c} \bar{a}\right)$, and here lies the point of confusion. (Recall that al-Albānī recognized invocation of the righteous as a permissible form of mediation.)

Before the coming of Islam, devotional attachment was idolatrous because its practitioners attributed lordship to the objects of their devotional attachment, thinking that the power of their idols to respond to their requests did not depend on God's favor (ridā allah). This was to make their idols equal to God. In contrast, Muslims who are devoted to holy persons do not think such figures can respond to their requests independently of God's favor. The confusion stems from verses in the Qur'an that deny the 
efficacy of intercession apart from God's permission and favor. This does not mean that special permission must be received in advance for a holy person to intercede on behalf of others. Why would Abraham have sought forgiveness from God for his father or Muhammad for his uncle? The word for permission (idhn) is to be understood in the same sense as favor (ridā), i.e. the will of God. A holy person can intercede without special permission, but the efficacy of his intercession is contingent on God's will. The requests of Abraham and Muhammad-forgiveness for polytheism-fell short of God's favor and were therefore not honored by God.

In contrast, the mistake of idolatry is to assume that idols possess the power to honor requests, including requests that do not meet God's favor, thereby attributing lordship to them apart from God. No one in the umma, Ibn Kīrān affirms, when seeking the intercession of saints or the blessing of their relics, believes that they can honor their requests without God's favor. Rather, they make the request in the hope that the saints will help them through their invocation and supplication, knowing full well that God will accept their intercession if he wills or reject it if he wills. After all, it is a basic belief in Islam that God is not bound in any way.

Thus, devotional attachment to holy persons actually reflects the deep hope of the umma to be accepted by God along with prophets and saints upon whom his mercies descend. Indeed, the generality of Muslim leaders have encouraged the practice, judging it to be praiseworthy, since the saints constitute gateways to God and God has made it his custom (sunna) to respond to requests through them. Ibn Kīrān mentions a number of scholarly works that approve the practice and detail proper guidelines for shrine visitation. Those who cannot visit the shrines of holy persons should convey their greetings to them, mentioning their needs and wants, for they are the generous masters (al-sādāt al-kirām) who never deny those who look to them as a means to God. This is particularly true in visiting the shrine of the prophet. Those who stand before his grave should feel as if they are standing in his presence during his lifetime. It has long been the consensus of the community that the prophet, whether alive or dead, is attending to the intentions of his followers, and it is impossible for the community to agree on error.

Ibn Kīrān is aware that the "innovator" (al-mubtadic) accepts the intercession of messengers (rusul) when alive but not when they are dead or absent in a distant place. This, he says, is simply a pretext to condemn those who call upon the dead when, as is known, the matter involves something unusual (kharq al-'äda), namely the ability of holy persons to hear and 
comprehend in extraordinary fashion, even in the grave. The innovator knows that God honors the umma with miracles (karāmāt) to its benefit. This in no way makes holy persons divine but gives them access to knowledge of the hidden realm (al-ghayb), access which God grants to whomever he wills.

This is not to overlook the verse in the Qur'an (72:27) that says that God grants access to such knowledge only to a messenger $(r a s \bar{u} l)$ in whom his favor rests. This, however, does not mean that such miracles are limited to the Prophet Muhammad. They also extend to the saints whose rank is not based in themselves but in their association with the light of the prophet. In this sense, the hadith that speaks of the prophets as alive in their graves applies to saints as well. The idea that the power of saints derives from their association with the prophet is central to Ibn Kïrān's line of thinking throughout the treatise.

Besides, it is a very grave matter to accuse someone of infidelity, tantamount to claiming that they will spend eternity in hell. It makes their life and property licit for the taking, denies them the right to marry a Muslim woman, and deprives them of judgment by the rulings of Islam. The companions taught that it is better to be mistaken in not killing a thousand infidels than to be mistaken in spilling the blood of a single Muslim. Prudence is to prevail above all in matters (masa $\left.\bar{a}^{\prime} i l\right)$ such as these where there is ambiguity (shubha) and disagreement (ikhtiläf) and, moreover, where there is a long-standing consensus of permissibility. A widely acknowledged report says that Adam sought forgiveness from God for his sin through the intercession of Muhammad whose name he saw written on God's throne alongside God's own name in the form of the two testimonies. Besides the reports that tell of people asking Muhammad, while alive, to intercede for them with God, there are also many reports of people doing so after his death. Ibn al-Nu'mān (d. 1284) has recorded these reports in Kitab Misbāh al-Zalām fì l-Mustaghïthìn bi-Khayr al-Anām from which Ibn Kīrān notes one example as narrated by Ahmad al-Qastallānī. ${ }^{16}$ Doctors had been unable to cure the ailment from which he had long suffered, and so he sought the assistance of Muhammad on the evening of 28 Jumādā alAwwal 898 AH while in Mecca. During his sleep that night, he saw a man writing on a sheet of paper, "This is the remedy for the ailment of Ahmad

16 This is Abu l-'Abbās Ahmad b. Muhammad al-Qastallānī (d. 1517), a Shāfíi Egyptian famous for his commentary on the hadith collection of al-Bukhārī and a biography of the prophet (al-Mawähib al-Laduniyya). 
al-Qastillānī from [the Prophet]." When he awoke, he had been completely healed by the blessing of Muhammad.

Since the prophet is undeniably a means to a favorable outcome in the next life, his relics are also a source of blessing for the faithful to seek. However, such a practice depends on one's intention. Since the ignorant masses (jahalat al-'awämm) do not pursue the practice with a sound intention, undermining its purpose, it is necessary to classify the practice as reprehensible, even if there are plenty of reports that describe the enthusiasm of the companions for things that came into contact with the prophet. Thus, the practice of seeking a blessing from the relics of the saints is also permissible since they have a share in the qualities of the prophet. No less a figure than Ahmad b. Hanbal ruled that there is no harm in kissing the prophet's grave. Malikism, for its part, judges this action to be reprehensible, but it is impossible to prevent it since it follows from the intense desire of devotees to be in contact with the object of their devotion. After all, Muslims have long been eager to pray in the exact spots where the prophet is known to have prayed, and Mu'āwiya commanded that he be buried with a piece of the prophet's hair, seeking its blessing, intercession, and mediation. The practice of seeking a blessing via relics has been transmitted from one generation to the next without repudiation. If it were forbidden, the lawgiver would have mentioned it. There have always been scholars who disapproved of the practice, but many others approved it, and some people have trouble setting their hearts on God, which is the goal of Islam, without the mediating assistance of relics.

To be sure, some behavior at shrines is offensive. It is forbidden to circumambulate around the shrine, as the ignorant do, but it is permissible to kiss shrines and rub against them. It is well-known that the delegation of 'Abd al-Qays kissed the hands and feet of the prophet, and a report in the Sunan of al-Bayhaqī (d. 1066) records that Abū 'Ubayda b. al-Jarrāh kissed the hand of 'Umar when he went to Damascus. Scholars permit such a sign of deference to those worthy of it. Some scholars permit kissing the graves of saints, copies of the Qur'an, and collections of hadith, and one scholar from Fez says that it is permissible to gather dust from the graves of the saints as a means of healing, claiming that the first Muslims did so with dust from the grave of the martyr-companion Hamza.

Against the innovator's claim that the first Muslims rejected the practice of uttering invocations at the graves of the righteous, Ibn Kinrān notes that a number of scholars permit invocations at these sites. The status that the 
inhabitants of these graves enjoy with God makes them sites for the diffusion of divine mercies. Interestingly, here as in other places, Ibn Kïrān defends the practice on the basis of experience (tajriba) in addition to revealed indicant and communal consensus. In other words, if it works, it must be acceptable to God.

One example is a widely accepted story, narrated by two scholars from Morocco. When in Medina, they saw a Bedouin make invocation at the prophet's grave, saying he had come to seek forgiveness for his sins through the prophet's intercession. That night while sleeping, one of the scholars saw a vision of the prophet who told him that the Bedouin had been forgiven through his intercession. This should not be surprising since the Qur'an says that God and his angels pray for the prophet, and as noted in a hadith, when one sees the prophet in a dream, it is truly him, since he is the one figure no demon could dissemble. As with previous topics, this practice, since permissible at the prophet's grave, is also permissible at the graves of saints. There are those who reject this, notably Abū Bakr Ibn al-Arabì (d. 1148), who said that no grave other than the prophet's is to be visited in order to seek a benefit. But the majority of scholars accept it. To be fair, Ibn al-Arabī may have issued this opinion to close the door to innovations that sometimes accompany the practice of making invocation at shrines, but there is no reason to rely on him alone.

A similar line of reasoning is applied to other practices associated with the cult of the saints. Visitation to the spiritual elite (khawāss al-umma), both living and deceased, is highly recommended. In several hadiths, the prophet states that visiting him after his death is like visiting him when alive, and this, again, extends to the saints. They are entirely united in him, and there is no difference, save in degree, in the grace ( $f a d l)$ to be received from visiting the graves of prophets, saints, and scholars, but it is better to visit the living than the dead since looking into the faces of the righteous is a kind of worship. As al-Ghazali noted (in the chapter of his magnum opus on spiritual companionship), visiting brothers in God is a source of grace. In other words, grace operates via spiritual companionship. The purpose of the visitation is exposure to the fragrances of divine mercy that are more intense at the graves of the righteous. In this sense, the dead, who are fully in the divine presence, are better able to help the petitioner than the living. To be sure, there are rules. One is not to pray upon graves or to build a mosque over them in the manner of Christians, and shrines should not be a place for congregation with women. Also, out of respect for the body, 
which enjoys inviolability even after death, one should not sit on the grave, and one should certainly not pray in the direction of graves as people did before the coming of Islam.

As for vows to holy persons in the grave, there is no revealed evidence that treats the subject, making it permissible so long as the purpose is to earn reward for the dead. In this sense, Ibn Kīrān associates the practice to the figh categories of charity (sadaqa) and gift-giving (hiba). For example, a vow to help the poor who gather at the saint's shrine is a way to benefit the dead (naf'al-mayyit) as a kind of indulgence on their behalf. As a result, scholars generally define the practice as a pious deed (qurba). What is principally at stake is the thing that is vowed to the holy person for his benefit. This is highly commendable, so how can one with no expertise label it idolatry and unbelief?

The practice of making a sacrifice at the graves of holy persons is more complex. As with vows, the purpose should be charity and not simply the spilling of the animal's blood, which is counted a pious deed only at the feast of the sacrifice. However, Ibn Kīrān admits, some have a strong desire to spill blood. It is not uncommon to see someone leave the animal after sacrificing it with no indication that they consider it charity. This reflects the customs of the region where many hope to attain the help of the saint in winning over a person of high rank or a tribe. The idea is that it would be a shame ( $(\bar{a} r)$ for the saint to whom the sacrifice is made to neglect the aspiration of the one who offers the sacrifice. This makes the sacrifice a way to compel the saint to intercede with God. This practice, imposing on the saints the demands of tribal customs that neither revelation nor nature requires is simply empty custom, but there is nothing in it that requires a judgment of idolatry and unbelief.

This is not to ignore the hadith that describes the curses written on the scroll that the prophet kept in the scabbard of his sword, including the curse on those who sacrifice to something other than God. However, as scholars explain, this entails invoking a name other than God's (bi-smi ghayrihi) when making sacrifice, e.g. the name of an idol, the cross, Jesus, or the Ka'ba, which is not the case when a Muslim sacrifices to a saint. Only the name of God is mentioned. Scholars do teach that the meat of these sacrifices is not to be eaten, but the one who makes the sacrifice is still a Muslim unless he elevates to the level of lordship the one to whom he sacrifices. Islam recognizes sacrifices that are not made to God, such as sacrifices made to welcome someone-a sultan or newborn. No one thinks this 
is forbidden. It is only when a sacrifice is made in a name other than that of God that it becomes apostasy. Even then, there is always opportunity to repent.

Wahhabism, Ibn Kīrān avows, has upset the umma by propagating its creed through the texts of revelation, but there is nothing there to support their claims, especially the charge that those verses in the Qur'an that condemn the worship of something short of God (dün allah) apply to devotional attachments to prophets and saints, since, in point of fact, no attribution of lordship or divinity accompanies these attachments. Indeed, some scholars permit the building of domes (but not mosques) over the graves of the righteous, covering them in silk cloth, and lighting candles in the vicinity. All of this facilitates the benefit people gain from visiting the saints, for it prevents the shrines from falling into disappear. Other nations allowed the shrines of their prophets to disappear without a trace, and this led to their own demise. (Presumably, a nation's sustainability depends on its devotion to its pious ancestors.) In this sense, Wahhabism has made a grievous mistake in condemning tawassul through the community's holy persons. Indeed, the practice is a sign of human reliance on the grace of God (fadl allah) that works through the special causality (tasabbub) of those God has honored. This is a sign of faith, which should not be confused with those who insult the prophet, make alcohol permissible, and require others to prostrate before them. After all, one can only be condemned for manifest signs of apostasy. Ibn Kīrān ends by quoting the innovator's claim that those deficient in the basics of Islam are no longer Muslim. Alas, our authority responds, the innovator has failed to see that faith is faith even if partial.

To conclude: Our goal has been to build upon previous studies that speak of reformist impulses in Morocco of the late eighteenth and early nineteenth centuries but that do not always situate texts, such as Ibn Kīran's refutation of Wahhabism, in relation to the socio-political context. It is, of course, difficult to know exactly why a theological text would be written, especially one that does not make reference to the socio-political issues of the day. Still, all literature bespeaks the concerns of the day, even if implicitly. To understand the way a particular work reflects those concerns requires a wider reading in the broader literature of the day. Here, we have only begun that process. By aligning the treatise to its context, particularly the attempts to project authority through religious reform, we suggest that Ibn Kīrān's refutation of Wahhabism is a way for him, too, to articulate his 
authority as premier religious scholar of the capital city of the realm. He is not simply refuting Wahhabism but also defining the forms of faith that the power of the realm is to defend as basis of its legitimacy. Theological discourse on the intercession of saints, both then and now, is not without a political message. 